\title{
Composition and Distribution on a Host of Avian Lice of White Storks in North-Eastern Algeria
}

\author{
Laïd Touati ${ }^{1,2}{ }^{-}$, Mohammed Athamnia ${ }^{2,3}$, Riad Nedjah ${ }^{2,3}$, Abdennour Boucheker ${ }^{2,4} \oplus$, Farrah Samraoui ${ }^{2,3}$, \\ Hamed A. El-Serehy ${ }^{5}$ and Boudjéma Samraoui $2,4, *$ (D) \\ 1 Department of Biology \& Plant Ecology, Mentouri Brothers University Constantine 1, \\ Constantine 25000, Algeria; laidbio@hotmail.com \\ 2 Laboratoire de Conservation des Zones Humides, Université 8 mai 1945, Guelma 24000, Algeria; \\ athamnia.mouh@yahoo.fr (M.A.); nedjah@live.com (R.N.); babdennour2007@yahoo.fr (A.B.); \\ fsamraoui@gmail.com (F.S.) \\ 3 Department of Ecology and Environmental Engineering, Université 8 mai 1945, Guelma 24000, Algeria \\ 4 Department of Biology, Badji Mokhtar University, Annaba 23000, Algeria \\ 5 Department of Zoology, College of Science, King Saud University, P.O. Box 2455, Riyadh 11451, Saudi Arabia; \\ hel_serehy@yahoo.com \\ * Correspondence: bsamraoui@gmail.com; Tel.: +213-542789610
}

Citation: Touati, L.; Athamnia, M.; Nedjah, R.; Boucheker, A.; Samraoui, F.; El-Serehy, H.A.; Samraoui, B. Composition and Distribution on a Host of Avian Lice of White Storks in North-Eastern Algeria. Diversity 2022 14, 77. https://doi.org/10.3390/ d14020077

Academic Editor: Luc Legal

Received: 21 December 2021

Accepted: 13 January 2022

Published: 22 January 2022

Publisher's Note: MDPI stays neutral with regard to jurisdictional claims in published maps and institutional affiliations.

Copyright: () 2022 by the authors. Licensee MDPI, Basel, Switzerland. This article is an open access article distributed under the terms and conditions of the Creative Commons Attribution (CC BY) license (https:// creativecommons.org/licenses/by/ $4.0 /)$.

\begin{abstract}
The diversity and spatial distribution of ectoparasites of a large colony of white stork Ciconia ciconia at Dréan, in north-eastern Algeria, were investigated during two consecutive breeding seasons. The results indicated that nestlings were infested by the following four louse species: Colpocephalum zebra (Burmeister, 1838), Neophilopterus incompletus (Denny, 1842), Ardeicola ciconiae (Linnaeus, 1758), and Ciconiphilus quadripustulatus (Burmeister, 1838). Overall, the distribution of chewing lice exhibited a clustered distribution, with $C$. zebra being the most frequent species, with a prevalence of $39.6 \%$ and $41.0 \%$ in 2011 and 2012, respectively. Our results also suggested niche partitioning among the four louse species within the host's body parts. A generalized additive model indicated that size, sex, and year influenced the abundance of ectoparasites; the abundance of chewing lice increased with the size of the host and was greater in females, as well as in the first year of study. Further studies are needed to explore the spatio-temporal variability in white storks' lice infestations.
\end{abstract}

Keywords: Ciconiiformes; diversity; ectoparasites; Phthiraptera; spatial distribution; Algeria

\section{Introduction}

Owing to complex interactions with their hosts, parasite diversity is an important selective force that drives population, community, and ecosystem dynamics. The influence of parasites on their hosts is manifold [1], and they can shape the behavior, population dynamics, and the evolution of their hosts. Thus, host survival, fecundity, quality of offspring, and mating success may all be modified by parasites [2-5]. Host strategies, however, for dealing with parasites are equally complex, often leading to an evolutionary arms race [6]. As ectosymbionts, lice have proved to be models of choice to study host-parasite co-adaptation and co-adaptive diversification [7].

Lice are one of the most widespread ectoparasites, due to their high reproductive efficiency, their ability to tolerate adverse conditions, and their elusiveness, making them pests that are capable of seriously debilitating, or even killing, their hosts [8]. Lice are traditionally divided into sucking lice and chewing lice, with more than 3000 species of chewing lice being recorded worldwide [9]. Furthermore, chewing lice are known as highly specialized, obligatory, and stationary ectoparasites of mammals and birds. They live on the feathers, skin, and hair of their hosts, which functions as their living environment, providing them with food and shelter [10]. Chewing lice may also have many of the structural and behavioral transformations that help them spend their life cycle with their 
hosts [11]. The role of ectoparasites in bird migration and in the dispersal of infectious diseases is understudied [12-15]. Although chewing lice are permanent and obligate ectoparasites with a high degree of host specificity $[16,17]$, some species exhibit lesser host specificity [18-21].

The white stork Ciconia ciconia (Linnaeus, 1758) is one of the most important indicators of environmental conditions, providing useful information on the biodiversity of agricultural rural areas [22]. The white stork is also a migratory bird with a breeding range that spans Europe, North Africa, and the Middle East [23]. The Algerian population is mainly confined to the coastal area and the Hauts Plateaux, with a few scattered nests on the northern fringes of the Sahara [24-26]. Most research has focused on the reproductive ecology of North African white storks [27-32]. In contrast, no systematic research has investigated the ectoparasites of this emblematic species [33]. Because studies of waterbirds' ectoparasites in Algeria are relatively recent, only a few species, such as the common coot Fulica atra [34], greater flamingo Phoenocopterus roseus [35], glossy ibis Plegadis falcinellus [36], little egret Egretta garzetta [37], and white stork [33], have been investigated. In addition, a checklist of ectoparasites of twelve bird species, including passerines and waterbirds, has been published by Baziz-Neffah et al. [38]. Thus, to date, there is scant information on chewing lice species that parasitize white storks, their distribution and impact on their hosts, and their geographical range. As a colonial species, white storks are expected to host more parasites than solitary species, assuming that the proximity of the hosts increases the probability of parasite transmission [39-41].

This study, part of a project investigating the ecology and population dynamics of a large colony of white storks at Dréan, in north-eastern Algeria [31,32], focuses on the ectoparasites found on nestlings, assesses changes in their abundance, and tests whether their distribution on their host's body parts is spatially structured.

\section{Materials and Methods}

White storks usually arrive at their Algerian breeding grounds in December/early January, before starting to breed at the end of February [32]. A small number of birds, however, reside all year round [42]. The nestling period is rather long, 63-71 days [23], and most chicks leave the nest in June and July. Prior to fledging, sampling of nestlings was carried out in 2011 and 2012 at a colony that sat in an olive grove of 25 ha, close to a refuse tip $\left(36^{\circ} 41^{\prime} 2^{\prime \prime} \mathrm{N}, 07^{\circ} 44^{\prime} 47^{\prime \prime}\right.$ E) (Figure 1). Nests were constructed in olive trees Olea europea with heights varying between $3.5 \mathrm{~m}$ and $6.5 \mathrm{~m}$. The colony's white storks used the refuse dump, an adjacent reservoir, and the surrounding agricultural fields as foraging grounds. The climate of the area is typically Mediterranean, divided into two periods, a rainy season (November-April) and a hot and dry season (May-October). Total annual rainfall ranged from 500 to $800 \mathrm{~mm}$ and air temperatures for the first six months (January-June) were similar for both study years, averaging $16.4^{\circ} \mathrm{C}$. It rained, however, substantially less during the first six months (September-February), preceding the onset of breeding in the first study year (520 $\mathrm{mm}$ in 2011 vs. $740 \mathrm{~mm}$ in 2012).

We looked for ectoparasites during the annual nestling ringing operation. A total of 59 and 61 nestlings were examined in 2011 and 2012, respectively. Each bird was handled for approximately $5 \mathrm{~min}$, with sampling of external parasites carried out by visual examination of six different body parts (head, wings, back, belly and breast, legs, and crissum and tail). The chewing lice were collected using a pair of tweezers and stored in tubes containing $70 \%$ ethanol until they were mounted on permanent slides, following the technique described by Palma [43], and deposited in the entomology collection of the Laboratoire de Conservation des Zones Humides (L.C.Z.H), University of Guelma. 


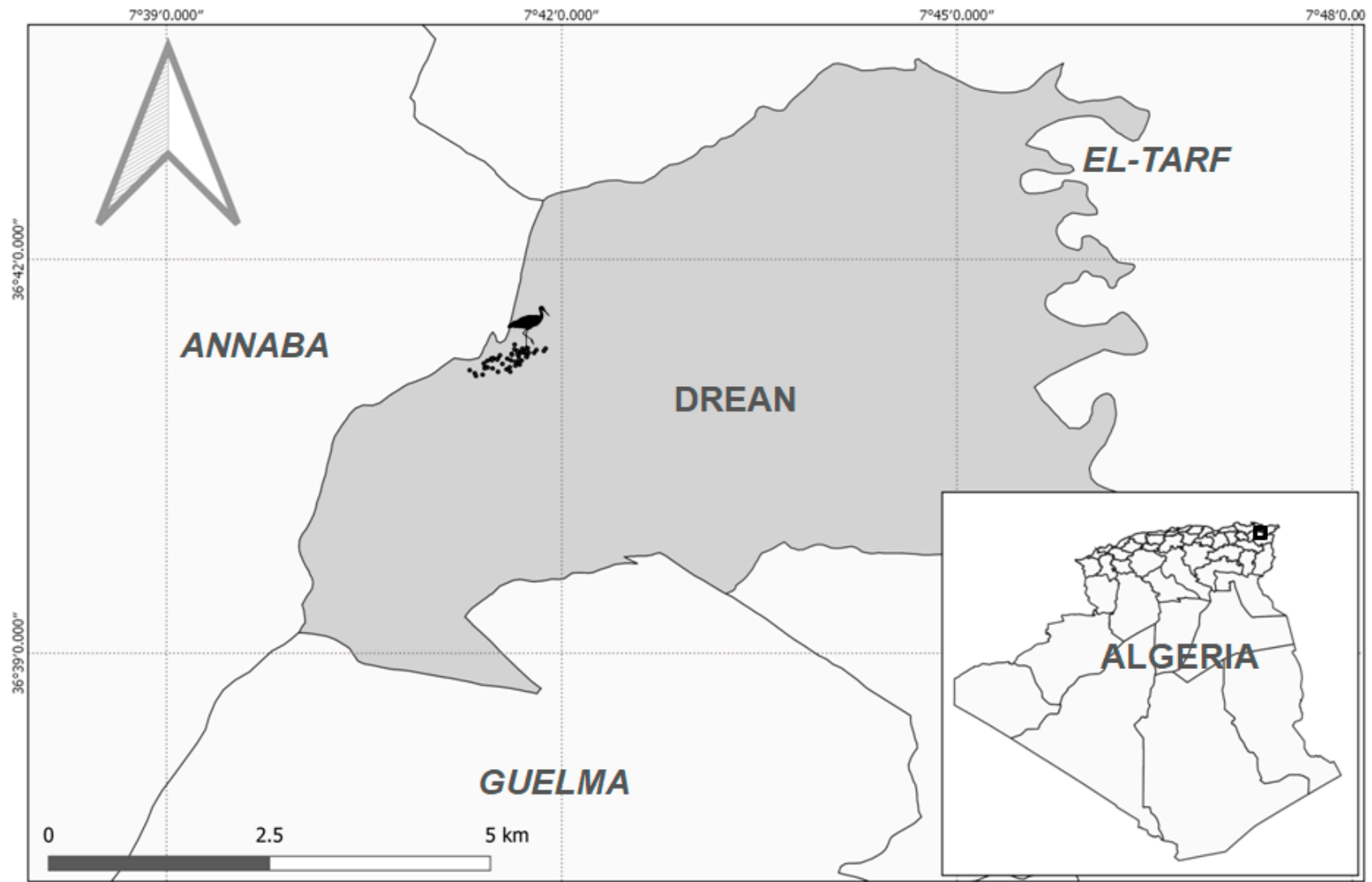

Figure 1. Map of Numidia, north-eastern Algeria, with the location of the studied white stork colony.

For identification, we proceeded with the help of various keys [44-46]. Recorded nestling measurements were body mass (measured with a spring balance with a precision of $0.1 \mathrm{~g}$ ), head-beak and tarsus lengths (measured with a sliding calliper to the nearest $0.1 \mathrm{~mm}$ ). Furthermore, the half-wing length was measured to the nearest $0.5 \mathrm{~mm}$ using a ruler. Feather samples were taken for DNA extraction and sex identification using polymerase chain reaction (PCR) amplification of the CHD genes [47].

Different indices were used to analyze the structure of the parasite community (prevalence, mean intensity, mean abundance, variance, and aggregation) [48-51]. In order to quantify the degree of aggregation, we calculated the ratio variance/mean abundance. This ratio, also named index of dispersion, can have the value unity representing random dispersion, whereas parasites dispersed regularly yield a ratio $<1$ and those dispersed contagiously yield a ratio $>1$.

\section{Statistical Analysis}

To test the influence of size, year, and sex of host on lice's abundance, we performed a generalized additive model (GAM) with a negative binomial distribution. An exploratory data analysis indicated that weight, tarsus, head and beak, and wing were collinear. We used weight as a proxy to size. Thus, size, year, and sex of hosts were used as fixed effects. Not all individuals were sexed and chicks with unknown sex were incorporated as "unknown". Model validation included tests of homogeneity, normality, influential observations, and independence, and was carried out to check the robustness of the model. Data analyses (Fisher's exact test, Kruskal-Wallis rank sum test, GAM) were carried out using R [52].

\section{Results}

The ectoparasite community consisted of the following four chewing louse species ( $\mathrm{Ph}$ thiraptera: Amblycera and Ischnocera) in both study years: Colpocephalum zebra (Burmeis- 
ter, 1838); Neophilopterus incompletus (Denny, 1842); Ardeicola ciconia (Linnaeus, 1758); Ciconiphilus quadripustulatus (Burmeister, 1838) (Table 1). Overall, 37 infested birds were recorded out of 120 sampled nestlings (30.8\%) and a total of 134 chewing lice were collected.

Table 1. Feather lice collected from white stork nestlings at Dréan (2011 and 2012) with prevalence, mean abundance and mean intensity of ectoparasites.

\begin{tabular}{cccccc}
\hline Ectoparasites & Year & Infested Hosts & Prevalence (\%) & $\begin{array}{c}\text { Mean Abundance } \\
( \pm \mathbf{s d})\end{array}$ & $\begin{array}{c}\text { Mean Intensity } \\
( \pm \mathbf{s d})\end{array}$ \\
\hline $\begin{array}{c}\text { Colpocephalum zebra } \\
\text { (Amblycera, Menoponidae) }\end{array}$ & 2011 & $10 / 59$ & 19.92 & $0.59 \pm 1.52$ & $1.4 \pm 2.12$ \\
\hline Neophilopterus incompletus & 2012 & $5 / 61$ & 8.19 & $0.27 \pm 1.02$ & $1.41 \pm 1.85$ \\
(Amblycera, Menoponidae) & 2012 & $3 / 61$ & 10.16 & $0.38 \pm 1.27$ & $0.92 \pm 1.2$ \\
\hline Ardeicola ciconiae & 2011 & $5 / 59$ & 4.91 & $0.16 \pm 0.72$ & $0.83 \pm 1.42$ \\
(Ischnocera, Philopteridae) & 2012 & $3 / 61$ & 8.47 & $0.37 \pm 1.2$ & $0.88 \pm 1.73$ \\
\hline Ciconiphilus quadripustulatus & 2011 & $4 / 59$ & 4.91 & $0.24 \pm 1.08$ & $1.25 \pm 2.14$ \\
(Ischnocera, Philopteridae) & 2012 & $1 / 61$ & 1.63 & $0.22 \pm 0.99$ & $0.52 \pm 1.53$ \\
\hline
\end{tabular}

In 2011, 25 out of 59 inspected nestlings were infested by lice (42.4\%). In total, 92 lice were collected, corresponding to 25 males $(27.2 \%), 57$ females $(62.0 \%)$, and 10 nymphs $(10.9 \%)$. The prevalence, mean abundance and mean intensity are presented in Table 1. The number of lice per individual bird ranged from one to seven (mean: 3.7), with most of the infested birds parasitized by only one species. With respect to relative frequencies, the ectoparasites community was dominated by C. zebra (19.9\%), and its mean abundance was $0.59 \pm 1.52$. The second most abundant taxa were N. incompletus $(10.2 \%)$, and the two other ectoparasites, A. ciconia, and C. quadripustulatus, were less common, with $8.5 \%$ and $6.8 \%$, respectively (Table 1 ).

In 2012, 61 nestlings were examined and only $12(19.6 \%)$ were recorded as being infested by louse species. A total of 42 lice, made up of 12 males (28.6\%), 24 females $(57.1 \%)$, and 6 nymphs $(14.3 \%)$, were collected from the sampled birds. The number of chewing lice per individual bird ranged from one to six (mean: 3.5), with, once more, the majority of infested birds parasitized by only one species. The ectoparasite community was dominated by C. zebra, with a prevalence of $8.2 \%$, followed by N. incompletus and A. ciconia, represented by the same percentage, $4.9 \%$. Finally, C. quadripustulatus was the least frequent, with $1.6 \%$ (Table 1 ). While the prevalence of the four chewing lice declined markedly during the second study year (Fisher's exact test for count data: $p=0.009$; CI: 1.24-7.46), the composition of the ectoparasites hosted by the white stork remained identical (Figure 2a).

\subsection{Spatial Distribution of Ectoparasites on Their Host}

With the exception of the legs, the chewing lice were distributed differentially on the body parts of their hosts for both of the two study years. In 2011, wings (59.1\%), and crissum and tail (19.4\%) supported the most ectoparasites. In contrast, relatively few were located on the head, the back (8.6\% for both parts), and the belly and breast (5.4\%) (Figure 2a). Similarly, in the following year, the wings harbored the greatest number of ectoparasites $(45.5 \%)$. The back $(18.2 \%)$ also supported a number of ectoparasites, slightly superior to other parts of the host's body. The same percentage of ectoparasites (13.6\%) was shared by the belly and breast. In contrast to the preceding year, the crissum and tail sheltered the lowest number of feather lice (Figure 2b). 


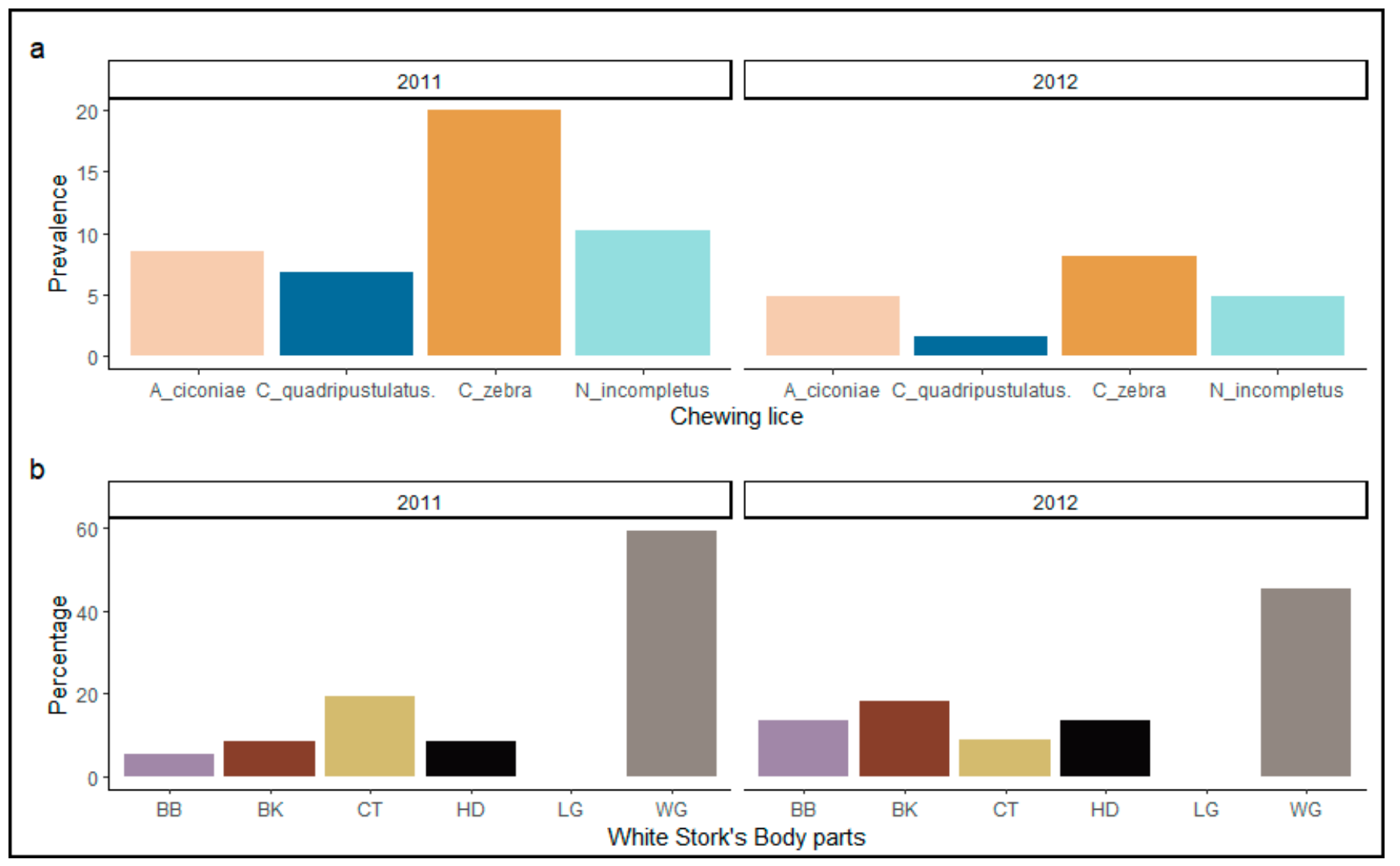

Figure 2. Temporal variation in prevalence of lice at the Dréan colony (a). Percentage of lice on the following different body regions of white stork nestlings: BB, breast and belly; BK, back; CT, crissum and tail; HD, head; LG, legs; WG, wings in 2011 and 2012 (b).

The spatial distribution of ectoparasites on the different parts of the host was heterogeneous in both study years. Overall, C. zebra, A. ciconiae, and C. quadripustulatus were the dominant species on the wings and other parts of the body. In contrast, N. incompletus was dominant on the breast and belly, and on the crissum and tail (Figure 3b). In 2011, C. zebra was found mainly on the wings $(89.5 \%)$ and the back (10.5\%) (Figure 3a), whereas $N$. incompletus was only recorded on the crissum and tail (78.3\%), and the belly and breast $(21.8 \%)$ (Figure $3 b)$. In contrast, A. ciconiae was noted on the following three major body parts: wings $(86.4 \%)$, head $(5.5 \%)$, and back (9.1\%) (Figure 3c). Similarly, C. quadripustulatus was recovered mainly on the head $(53.8 \%)$, and, to a lesser extent, on the wings $(30.8 \%)$ and back $(15.4 \%)$ (Figure 3d).

In 2012, C. zebra was found mainly on the wings (66.7\%), and was present on the head (5.6\%) and the back, with a proportion of $27.8 \%$ (Figure 3a). In contrast, N. incompletus was encountered on its privileged areas, as follows: the breast and belly $(60 \%)$, and crissum and tail ( $40 \%$ ) (Figure 3b). The distribution pattern of Ardeicola ciconiae remained stable over the two study years, and it was recorded in 2012 on the following three distinct parts of the host body: the wings, with a relatively high value of $57.1 \%$; the head and the back, with the same percentage of $21.4 \%$ (Figure 3c). Finally, C. quadripustulatus was found to be confined to the head of white storks (Figure 3d). 


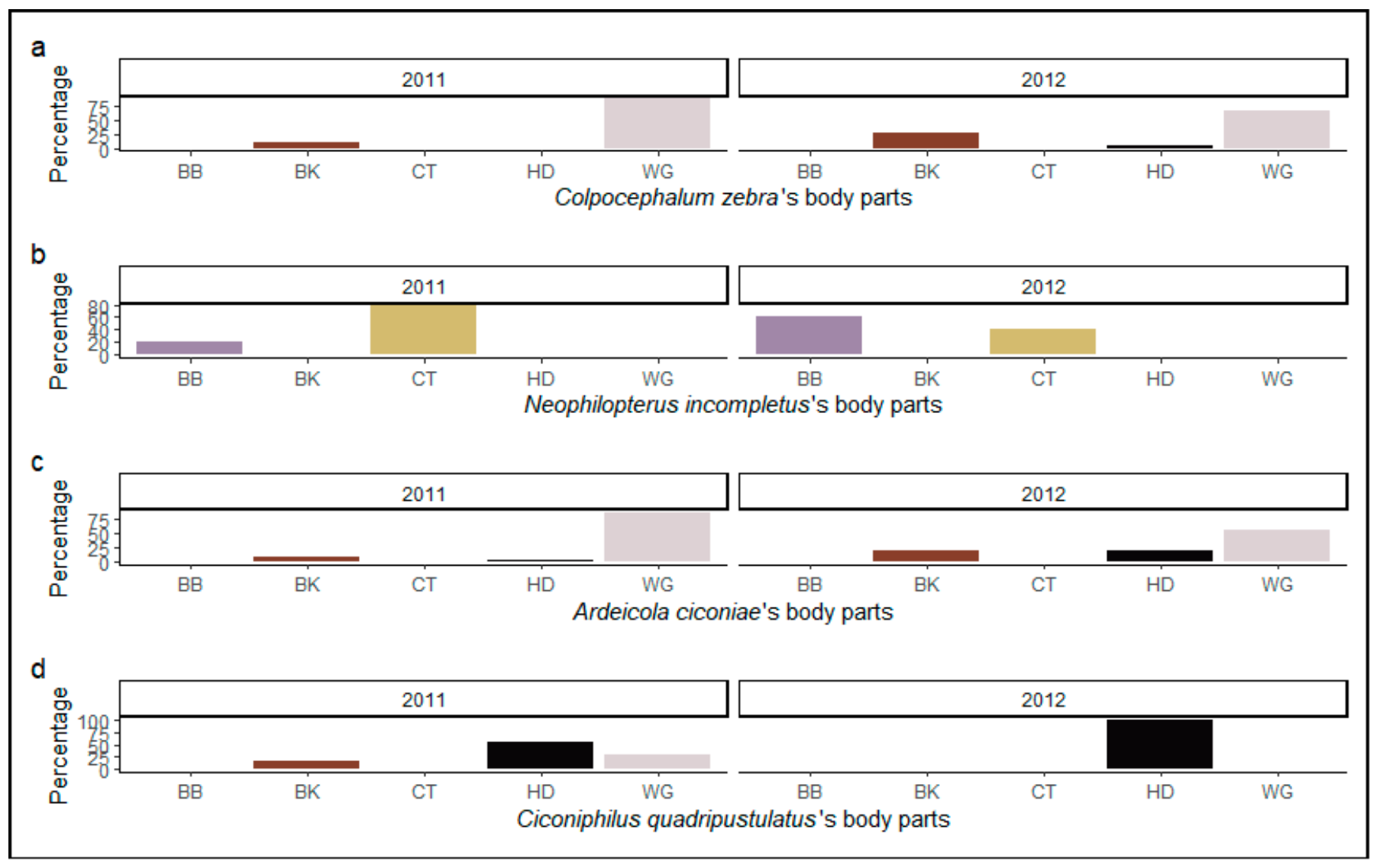

Figure 3. Frequency and spatial distribution of (a) Colpocephalum zebra; (b) Neophilopterus incompletus; (c) Ardeicola ciconiae; (d) Ciconiphilus quadripustulatus on five body parts of white stork nestlings in 2011 and 2012. BB, breast and belly; BK, back; CT, crissum and tail; HD, head; WG, wings.

\subsection{Aggregation}

During 2011, the mean abundance of C. zebra (0.59) was very much lower than the variance value of 2.31. The ratio (variance/mean abundance) was 3.9, thus highlighting the aggregated distribution of C. zebra. This typical distribution for parasites was found in $N$. incompletus (4.2), A. ciconia (3.9), and C. quadripustulatus (4.7) (Table 2). Similarly, in 2012, the index of dispersion varied between two for C. quadripustulatus and five for $A$. ciconiae (Table 2).

Table 2. The index of dispersion for feather lice at Dréan (2011 and 2012).

\begin{tabular}{clccc}
\hline Ectoparasites & Year & Variance $\mathbf{( S}^{\mathbf{2}}$ ) & Mean Abundance ( \pm sd) & Index of Aggregation \\
\hline Colpocephalum zebra & 2011 & 2.31 & $0.59 \pm 1.52$ & 3.91 \\
(Amblycera, Menoponidae) & 2012 & 1.02 & $0.27 \pm 1.02$ & 3.77 \\
\hline Neophilopterus incompletus & 2011 & 1.59 & $0.38 \pm 1.27$ & 4.18 \\
(Amblycera, Menoponidae) & 2012 & 0.53 & $0.16 \pm 0.72$ & 3.31 \\
\hline Ardeicola ciconiae & 2011 & 1.44 & $0.37 \pm 1.2$ & 3.89 \\
(Ischnocera, Philopteridae) & 2012 & 1.20 & $0.24 \pm 1.08$ & 5.00 \\
\hline Ciconiphilus quadripustulatus & 2011 & 1.03 & $0.22 \pm 0.99$ & 4.68 \\
(Ischnocera, Philopteridae) & 2012 & 0.06 & $0.03 \pm 0.25$ & 2.00 \\
\hline
\end{tabular}

The GAM model (deviance explained $=22.4 \%, \mathrm{n}=111$ ) indicated a significant effect of host size, sex, and year on the abundance of lice (Table 3). The positive relationship for size was linear (Figure 4). The results of the GAM also revealed that, after accounting for 
size, there was a significant decline in abundance between the two study years. Finally, the abundance of lice was greater in females than in males and unsexed chicks.

Table 3. Estimated regression parameters, standard errors, $z$-values, and $p$-values for the GAM.

\begin{tabular}{ccccc}
\hline Parametric Coefficients & Estimate & Std. Error & $z$-Value & $p$-Value \\
\hline Intercept & -0.48 & 1.1 & -0.44 & 0.662 \\
\hline Weight & $9.60 \times 10^{-4}$ & $4.50 \times 10^{-4}$ & -2.15 & 0.031 \\
\hline Year_2012 & -1 & 0.44 & -2.29 & 0.022 \\
\hline Sex_Male & -1.16 & 0.58 & -1.99 & 0.046 \\
\hline Sex_Unknown & -2.2 & 0.51 & -4.36 & $1.33 \times 10^{-5}$ \\
\hline
\end{tabular}

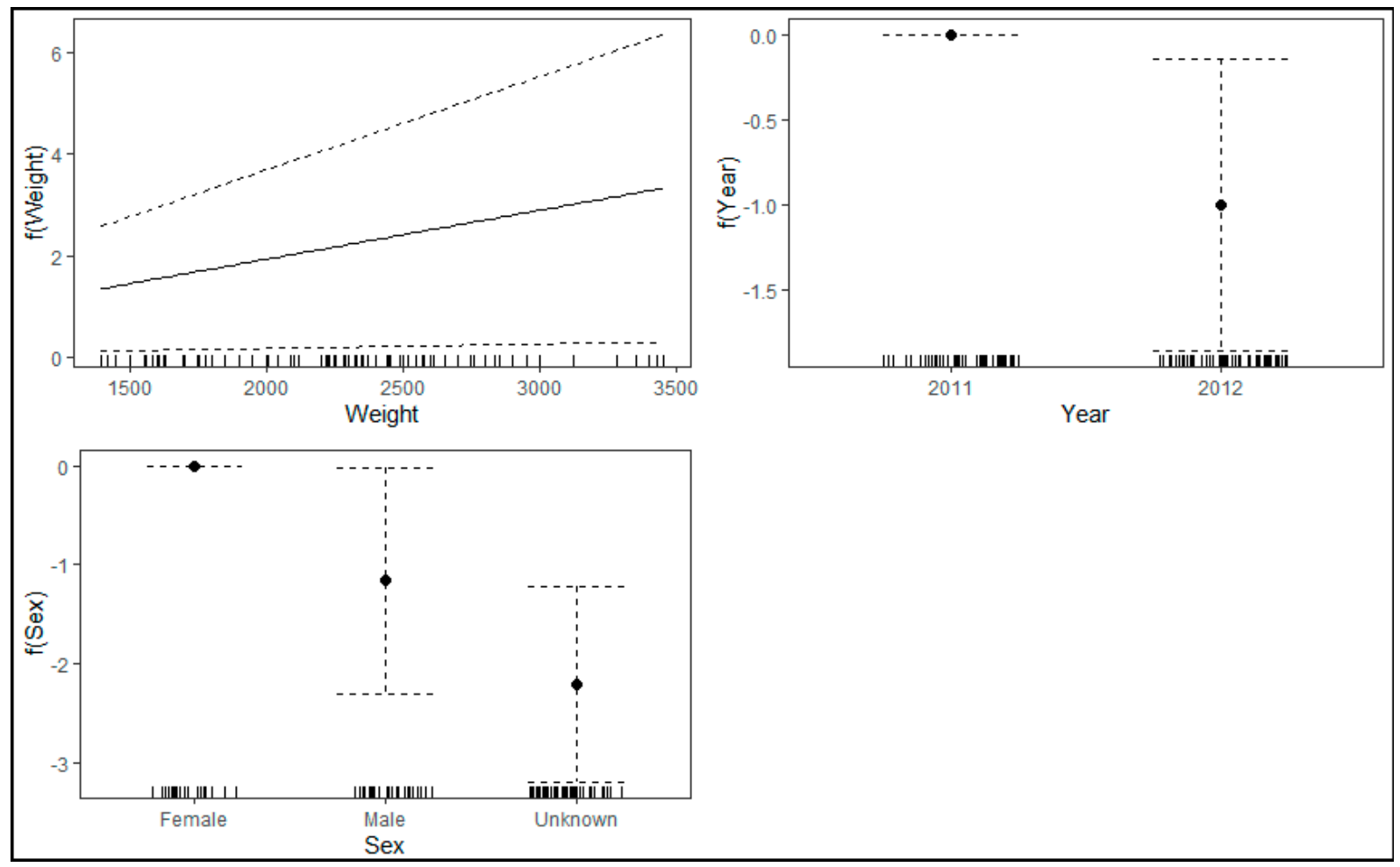

Figure 4. GAM model fit displaying lice's abundance against host size (weight), year, and sex.

\section{Discussion}

The ectoparasite community of the Dréan white storks was mainly dominated by chewing lice, with the following four species: Colpocephalum zebra, Neophilopterus incompletus, Ardeicola ciconiae, and Ciconiphilus quadripustulatus. These four genera, Colpocephalum, Neophilopterus, Ardeicola, and Ciconiphilus, are known as common ectoparasites of the Ciconiiformes [53-63]. In addition, all four species were previously recorded from Ciconia ciconia $[9,33,45,64,65]$. Similarly, a previous study in Romania showed that the most abundant taxa were C. zebra and N. incompletus [66]. Our results also support the results of Dik and Uslu [65] on storks examined in Turkey, where a high number of lice from four specific species were recorded, with the most dominant being C. zebra and N. incompletus.

The level of infestation depends on the concentration or density of birds, with ectoparasites spreading easily within a dense population. Thus, the number and variety of ectoparasites are greater on colonial birds than on territorial birds [41]. The density of the Dréan colony did not change between the two study years and our results did not reveal any between-year variation in the composition of the ectoparasites hosted by the white stork chicks. There was, however, a difference in prevalence levels between the two study 
years. Generally, variation in the parasitic fauna may be linked to climatic factors, such as temperature, humidity, and vegetation, which may limit the distribution [7]. Further investigations are required to uncover the causes of variation in the Dréan colony.

Ectoparasite infracommunities are spatially structured in relation to the host's body, and the spatial distribution of chewing lice is, in part, driven by feather morphology and chemistry [7]. Our results show that ectoparasites inhabit the following different body parts of white stork chicks: head, wings, back, breast and belly, and crissum and tail. While some ectoparasites exhibited no microhabitat preferences, others tended to confine themselves to limited areas of their host's body $[20,67,68]$. The differential abundance of the four species on the different parts of their hosts is indicative of apparent ecological partitioning among them. C. zebra was mainly located on the wings and the back [9]. The finding that Colpocephalum was mainly located on the wings agrees well with the ecological study of lice in domestic pigeons [69].

Another genus, Ardeicola, is also found on the wings, and is known as a wing louse of Ciconiiformes, being recorded throughout the order and differing only specifically on different hosts [67]. These findings agree with previous observations that slender, elongate lice inhabit wing feathers [70]. Both Colpocephalum and Ardeicola are found at lower densities on the head and the back of birds, but they rarely, if ever, co-occur with high densities on the wings of the same host. There is probably competition between the two species in the preferred area of the same host, and the distribution of the two species is distinct in the other body parts, as follows: dorsal parts in the case of Colpocephalum, and the head and back for Ardeicola.

Habitat preferences and competition avoidance may also explain the distribution of $N$. incompletus, which was mainly recorded in the crissum and tail, and the belly and breast. Size and morphological differences between parasite species may be a likely explanation for the microhabitat preferences. Similarly, the high frequency of $C$. quadripustulatus found on the head of white storks reflects the preferred location on the host's body. Species living on the head and neck are in little danger of being removed by the host's beak during preening, and tend to be slow-moving, round-bodied lice with relatively large heads and mandibles. In contrast, slimmer, more elongated lice are free to exploit the remainder of the host's body, since they can move easily and rapidly among the feathers to avoid the host's beak $[17,71]$. In the dorsal area, C. quadripustulatus has a body shape that makes it easier to attach onto the feather surface and can cling firmly with its strong legs. Differences in the size and shape of the feathers seem to provide the necessary habitat heterogeneity for parasites to segregate [72]. Indeed, most studies suggest that feather morphology and the ability of chewing lice to escape preening are the major factors determining the distribution of lice on birds [7,73], and preening is the main defensive behavior of birds against harmful ectoparasites [74].

\subsection{Aggregation and Sex Ratio}

Lice are known to exhibit an aggregated distribution within their hosts $[75,76]$. The clustered dispersion of Colpocephalum zebra suggests its occurrence within the colony for a long period of time, with a full spreading process across its members. Among the ten birds found infected in 2011, we found both mature female and male lice. In the other three hosts, we found either females and nymphs or only males and nymphs. In this case, reproduction and development of the parasite would only be possible if at least one of the nymphs was of the opposite sex. We recorded females, males, and nymphs for three species ( N. incompletus, A. ciconiae, and C. quadripustulatus), which would facilitate the process of reproduction. On the other hand, some nestlings hosted either females or males, and it is probable that these individuals were infected shortly before being sampled, by direct contact with infected siblings or adults exhibiting a higher intensity of infestation. 


\subsection{Factors Affecting Louse Abundance}

Our results are congruent with previous research, indicating that louse abundance is significantly correlated with host body mass $[77,78]$. A larger body size offers more resources and represents more refugia [77]. In contrast, the relationship between louse abundance and the host's sex is unclear, a result possibly constrained by the limited quantitative resolution of the sampling method used [79], and should be probed further. Similarly, the yearly variation in louse abundance deserves further investigation. In regards to the importance of humidity to the population dynamics of chewing lice [7], climatic factors deserve close scrutiny.

\section{Conclusions}

Four louse species (Colpocephalum zebra, Neophilopterus incompletus, Ardeicola ciconiae, and Ciconiphilus quadripustulatus) infested white storks' chicks at the Dréan colony, with the former being the most frequent ectoparasite. Owing to the lengthy nestling period and the offspring care provided by parents, these chewing lice were probably transmitted vertically between adults and offspring in the nest, with a varying degree of horizontal transmission between nestlings [80,81]. Our results also suggest niche partitioning among the four louse species within the host's body parts. A generalized additive model indicated that host size, sex, and year influenced the abundance of ectoparasites; the abundance of chewing lice increased with the size of the host and was greater in females, as well as in the first study year.

Author Contributions: Conceptualization, B.S. and L.T.; methodology, L.T. and B.S.; software, A.B.; validation, F.S.; formal analysis, L.T. and B.S., investigation, L.T., M.A., R.N. and A.B.; resources, H.A.E.-S.; data curation, L.T.; writing-original draft preparation, L.T. and B.S.; writing-review and editing, all authors; visualization, A.B. and B.S.; supervision, F.S.; project administration, F.S.; funding acquisition, H.A.E.-S. All authors have read and agreed to the published version of the manuscript.

Funding: This research was supported by King Saud University, Riyadh, Saudi Arabia, through the Researchers Supporting Project Number (RSP-2021/19).

Institutional Review Board Statement: This study was approved by the M.E.S.R.S. and all procedures followed were in accordance with international ethical standards.

Data Availability Statement: Data are available upon request.

Acknowledgments: We are most grateful to three anonymous reviewers for their helpful comments and suggestions. We are also indebted to Jordi Figuerola (Estación Biológica de Doñana, CSIC) for DNA-based sex identification of white stork nestlings. We acknowledge the material support of King Saud University, Riyadh, Saudi Arabia, through the Researchers Supporting Project Number (RSP-2021/19).

Conflicts of Interest: The authors declare no conflict of interest.

\section{References}

1. Proctor, H.; Owens, I. Mites and birds: Diversity, parasitism and coevolution. Trends Ecol. Evol. 2000, 15, 358-364. [CrossRef]

2. Møller, A.P. Effects of parasitism by a haematophagous mite on reproduction in the Barn Swallow. Ecology 1990, 71, 2345-2357. [CrossRef]

3. Lehmann, T. Ectoparasites: Direct impact on host fitness. Parasitol. Today 1993, 9, 8-12. [CrossRef]

4. Brown, C.R.; Brown, M.B.; Rannala, B. Ectoparasites reduce long-term survival of their avian host. Proc. R. Soc. Lond. Ser. B-Biol. Sci. 1995, 262, 313-319.

5. Barbosa, A.; Merino, S.; De Lope, F.; Møller, A.P. Effects of feather lice on flight behavior of male Barn Swallows (Hirundo rustica). Auk 2002, 119, 213-216. [CrossRef]

6. Sheath, D.J.; Dick, J.T.A.; Dickey, J.W.E.; Guo, Z.; Andreou, D.; Britton, J.R. Winning the arms race: Host-parasite shared evolutionary history reduces infection risks in fish final hosts. Biol. Lett. 2018, 14, 20180363. [CrossRef] [PubMed]

7. Clayton, D.H.; Bush, S.E.; Johnson, K.P. Coevolution of Life on Hosts; University of Chicago Press: Chicago, IL, USA; London, UK, 2016.

8. Permin, A.; Hansen, J.W. Epidemiology, Diagnosis and Control of Poultry Parasites FAO Animal Health Manuals 4; Food and Agriculture Organization of the United Nations (FAO): Rome, Italy, 1998. 
9. Fryderyk, S.; Izdebska, J.N. Chewing Lice (Insecta, Phthiraptera,) of the White Stork (Ciconia ciconia L.) in Poland. Ann. Univ. Mariae Curie Sk. 2009, 64, 83-85. [CrossRef]

10. Proctor, H.C. Feather Mites (Acari: Astigmata): Ecology, behavior, and evolution. Annu. Rev. Entomol. 2003, 48, 185-209. [CrossRef]

11. Horak, I.; Gallivan, G.; Braack, L.; Boomker, J.; Devos, V. Parasites of domestic and Wild animals in South Africa. XLI. Arthropod parasites of impalas, Aepyceros melampus, in the Kruger National Park. Onderstepoort J. Vet. Res. 2005, 70, $131-163$.

12. Hubálek, Z. An Annotated Checklist of Pathogenic Microorganisms Associated with Migratory Birds. J. Wildl. Dis. 2004, 40, 639-659. [CrossRef]

13. Sychra, O.; Literak, I.; Podzemny, P.; Benidekt, V. Insect ectoparasites from wild passerine birds in the Czech Republic. Parasite 2008, 15, 599-604. [CrossRef] [PubMed]

14. Palomar, A.; Santibáñez, P.; Mazuelas, D.; Roncero, L.; Santibáñez, S.; Portillo, A.; Otéo, J.A. Role of Birds in Dispersal of Etiologic Agents of Tick-borne Zoonoses, Spain, 2009. Emerg. Infect. Dis. 2012, 18, 1188-1191. [CrossRef] [PubMed]

15. Arnal, A.; Gómez-Díaz, E.; Cerdà-Cuéllar, M.; Lecollinet, S.; Pearce-Duvet, J.; Busquets, N.; García-Bocanegra, I.; Pages, N.; Vittecoq, M.; Hammouda, A.; et al. Circulation of a Meaban-Like Virus in Yellow-Legged Gulls and Seabird Ticks in the Western Mediterranean Basin. PLoS ONE 2014, 9, e89601. [CrossRef] [PubMed]

16. De Brooke, M.L.; Nakamura, H. The acquisition of host-specific feather lice by common cuckoos (Cuculus canorus). J. Zool. 1998, 244, 167-173. [CrossRef]

17. Johnson, K.P.; Bush, S.E.; Clayton, D. Correlated evolution of host and parasite body size: Tests of Harrison's rule using bird sandlice. Evolution 2005, 59, 1744-1753. [CrossRef]

18. Clay, T. Geographical distribution of the Mallophaga (Insecta). Bull. Br. Ornithol. Club 1964, 84, 14-16.

19. Choe, J.C.; Kim, K.C. Ectoparasites of the pelagic cormorant Phalacrocorax pelagicus from the Pribilof Islands, Alaska. J. Med. Entomol. 1987, 24, 584-592. [CrossRef] [PubMed]

20. Choe, J.C.; Kim, K.C. Microhabitat preference and coexistence of ectoparasites arthropods on Alaskan seabirds. Can. J. Zool. 1988, 66, 987-997. [CrossRef]

21. Wecksten, J.D. Biogeography explains phylogenetic patterns in toucan chewing lice. Syst. Biol. 2004, 53, 154-164. [CrossRef] [PubMed]

22. Gotkiewicz, W.; Wittbrodt, K. White stork (Ciconia ciconia L.) as an indicator of natural environment status in agricultural areas, illustrated with an example of Masurian Landscape Park. Environ. Prot. Nat. Resour. 2019, 30, 1-6. [CrossRef]

23. Cramp, S.; Simmons, K.E.L. HandBook of the Birds of Europe, the Middle East and North Africa: The Birds of the Western Palearctic. Volume 1, Ostrich to Ducks; Oxfords University Press: New York, NY, USA, 1977.

24. Heim de Balsac, H.; Mayaud, N. Les Oiseaux du Nord-Ouest de l'Afrique; Paul Lechevalier: Paris, France, 1962.

25. Isenmann, P.; Moali, A. Birds of Algeria; SEOF: Paris, France, 2000.

26. Samraoui, B.; Samraoui, F. An ornithological survey of the wetlands of Algeria: Important Bird Areas, Ramsar sites and threatened species. Wildfowl 2008, 58, 71-98.

27. Boukhemza, M.; Boukhemza-Zemmouri, N.; Voisin, J.-F. Biologie et écologie de la reproduction de la Cigogne blanche (Ciconia ciconia) dans la vallée du Sébaou (Kabylie, Algérie). Aves 2007, 44, 213-222.

28. Djerdali, S.; Tortosa, F.S.; Hillstrom, L.; Doumandji, S. Food supply and external cues limit the clutch size and hatchability in the White Stork Ciconia ciconia. Acta Ornithol. 2008, 43, 145-150. [CrossRef]

29. Si Bachir, A.; Chenchouni, H.; Djeddou, N.; Barbraud, C.; Céréghino, R.; Santoul, F. Using self-organizing maps to investigate factors regulating colony size and breeding success of the White Stork (Ciconia ciconia). J. Ornithol. 2013, 154, 481-489. [CrossRef]

30. Benharzallah, N.; Si Bachir, A.; Taleb, F.; Barbraud, C. Factors affecting growth parameters of White Stork nestlings in eastern Algeria. J. Ornithol. 2015, 156, 601-612. [CrossRef]

31. Bouriach, M.; Samraoui, F.; Souilah, R.; Houma, I.; Razkallah, I.; Alfarhan, A.H.; Samraoui, B. Does core-periphery gradient determine breeding performance in a breeding colony of White Storks Ciconia ciconia? Acta Ornithol. 2015, 50, 149-156. [CrossRef]

32. Belabed, B.-E.; Athamnia, M.; Touati, L.; Samraoui, F.; Boucheker, A.; Samraoui, B. The early bird catches the worm: Age-specific arrival time influences reproductive performance in the White Stork Ciconia ciconia. Bird Study 2019, 66, 121-129. [CrossRef]

33. Bouguessa-Cheriak, L.; Doumandji, S.; Ould Messaoud, S.; Marniche, F. Insect ectoparasites on the White Stork, Ciconia ciconia (L.) (Ciconiiformes: Ciconiidae), during breeding period in the extreme east of Algeria. Muzeul Olteniei Craiova. Oltenia-Studii şi comunicări Ştiinţele Naturii. 2017, 33, 72-78.

34. Rouag-Ziane, N.; Boulahbal, A.; Gauthier-Clerc, M.; Thomas, F.; Chabi, Y. Inventory and quantification of the ectoparasites of the common Coot Fulica atra (Gruiformes: Rallidae) in the northeast of Algeria. Parasite 2007, 14, 253-256. [CrossRef] [PubMed]

35. Touati, L.; Samraoui, B. Diversity and distribution of avian lice on chicks of Greater Flamingo (Phoenicopterus roseus) in Algeria. Avian Biol. Res. 2013, 6, 61-68. [CrossRef]

36. Touati, L.; Figuerola, J.; Samraoui, B. Patterns in the distribution of avian ectoparasites on Glossy Ibis chicks Plegadis falcinellus in Algeria. Zool. Ecol. 2015, 25, 46-53. [CrossRef]

37. Temimi, I.; Marniche, F.; Lazli, A.; Milla, A.; Dik, B. The study of the parasites of the bird Egretta garzetta (Linnaeus, 1766) (Aves: Ardeidae) in northeastern of Algeria. Muzeul Olteniei Craiova. Oltenia-Studii şi Comun. Ştiinţele Naturii. $2017,33,65-68$.

38. Baziz-Neffah, F.; Bitam, I.; Kernif, T. Contribution to the knowledge of ectoparasites of birds in Algeria. Bull. Soc. Zool. Fr. 2015, $140,81-98$. 
39. Møller, A.P. Advantages and disavantages of coloniality in the swallow (Hirundo rustica). Anim. Behav. 1987, 35, 819-832. [CrossRef]

40. Møller, A.P.; Dufva, R.; Allander, K. Parasites and the evolution of host sexual behavior. Adv. Study Behav. 1993, 22, 65-102.

41. Rózsa, L.; Rékázi, J.; Reiczigel, J. Relationship of host coloniality to the population ecology of avian lice (Insecta: Phtiraptera). J. Anim. Ecol. 1996, 65, 242-248. [CrossRef]

42. Samraoui, B. White Storks wintering in northeast Algeria. Br. Birds 1998, 91, 377.

43. Palma, R.L. Slide-mounting of lice: A detailed description of the Canada balsam technique. N. Zeal. Entomol. 1978, 6, 432-436. [CrossRef]

44. Séguy, E. Faune de France, 43. Insectes Ectoparasites (Mallophages, Anoploures, Siphonaptères); Paul Lechevalier: Paris, France, 1944.

45. Price, R.D.; Hallenthal, R.A.; Palma, R.L.; Johnson, K.P.; Clayton, D.H. The Chewing Lice the World. World Checklist and Biological Overview; Illinois Natural History Survey Special Publication: Champaign, IL, USA, 2003; Volume 24.

46. Wall, R.; Shearer, D. Veterinary Ectoparasites: Biology, Pathology and Control; Blackwell Science: Hoboken, NJ, USA, 2008.

47. Griffith, R.; Double, M.C.; Orr, K.; Dawson, R.J.G. A DNA test to sex most birds. Mol. Ecol. 2002, 7, 1071-1075. [CrossRef]

48. Margolis, L.; Eschi, G.W.; Holmes, J.-C.; Kuris, A.M.; Shad, G.A. The use of ecological terms in parasitology (report of an ad hoc committee of the American Society of Parasitologists). J. Parasitol. 1982, 68, 131-133. [CrossRef]

49. Fowler, J.; Cohen, L. Statistics for Ornithologists, 2nd ed.; BTO Guide N.2; British Trust for Ornithology: Thetford, UK, 1996.

50. Bush, A.O.; Lafferty, K.D.; Lotz, J.M.; Stak, A.W. Parasitology meets ecology on its own terms: Margolis et al. revisited. J. Parasitol. 1997, 83, 575-583. [CrossRef] [PubMed]

51. Wilson, K.; Bjornstad, O.N.; Dobson, P.; Merler, S.; Poglayen, G.; Randolph, S.E.; Read, A.F.; Skorping, A. Chapter2: Heterogeneities in macroparasites infections: Patterns and processes. In The Ecology of Wildlife Diseases; Hudson, P.J., Rizzoli, A., Grenfell, B.T., Heesterbeek, H., Dobson, A.P., Eds.; Oxford University Press: Oxford, UK, 2001; pp. 6-44.

52. R Development Core Team. R: A Language and Environment for Statistical Computing; R Core Team: Vienna, Austria, 2021.

53. Tendeiro, J. Estudos sobre uma Colecção de malóphagos de aves. Bol. Cult. Da Guiné Port. 1955, 35, 497-625.

54. Carriker, M.A. On the genera "Ciconiphilus" and "Ardeiphilus" with description of six new species. Rev. Bras. de Biol. 1964, 24, 95-108.

55. Price, R.D.; Beer, J.R. Colpocephalum (Mallophaga: Menoponidae) of the Ciconiiformes. Ann. Entomol. Soc. Am. 1965, 1, 111-131. [CrossRef]

56. Price, R.D.; Beer, J.R. A review of Ciconiphilus Bedford (Mallophaga: Menoponidae). Can. Entomol. 1965, 97, 657-666. [CrossRef]

57. Price, R.D.; Emerson, K.C. Two new species of Colpocephalum (Mallophaga: Menoponidae) from Neotropical Ciconiiformes. Ann. Entomol. Soc. Am. 1967, 60, 875-878. [CrossRef]

58. Tuff, D.W. A review of North American Ardeicola (Mallophaga: Philopteridae). J. Kans. Entomol. Soc. 1967, 40, $241-263$.

59. Price, R.C. A new species of Colpocephalum (Phtiraptera) on Threskiornis (Aves) from Aldabra. Syst. Entomol. 1976, 1, 61-63. [CrossRef]

60. Hajela, K.P.; Tandan, B.K. Species of Ardeicola (Insecta: Mallophaga) parasitic on birds of the family Threskiornithidae. Zool. J. Linnaean Soc. 1970, 49, 309-334. [CrossRef]

61. Martin Mateo, M.P. Phtiraptera from Platalea leucorodia (L.) (Aves: Ciconiiformes: Threskiornithidae) in Spain. Res. Rev. Parasitol. 1994, 54, 109-115.

62. Martin Mateo, M.P. Mallophaga, Amblycera. In Fauna Iberica; Ramos, M.A., et al., Eds.; Nacional de Ciencias Naturales Consejo Superior de Investigaciones Cientificas: Madrid, Spain, 2002; Volume 20, pp. 1-187.

63. İnci, A.; Yıldırım, A.; Dik, B.; Düzlü, O. Current knowledge of Turkey's louse fauna. Türkiye Parazitoloji Dern. 2011, 34, 212-220. [CrossRef]

64. Martin Mateo, M.P. Maláfagos (Insecta) parásitos de la cigüeña comun, Ciconia ciconia (L.) (Aves). Rev. Esp. Entomol. 1988, 64, 147-158.

65. Dik, B.; Uslu, U. Mallophaga (Insecta) species occurring on Storks (Ciconia ciconia) Linnaeus, 1758). Turk. Soc. Parasitol. 2006, 30, 220-225.

66. Adam, C. Data on the chewing louse fauna (Phthiraptera: Amblycera, Ischnocera) from some Romanian autochthonous and exotic birds. Trav. du Mus. Natl. d'histoire Nat. "Grigore Antipa" 2007, 50, 145-210.

67. Clay, T. Some problems in the evolution of a group of ectoparasites. Evolution 1949, 3, 279-299. [CrossRef] [PubMed]

68. Palma, R.L.; Johnson, A.R.; Cezilly, F.; Thomas, F.; Renaud, F. Diversity and distribution of feather lice on Greater Flamingoes (Phoenicopterus ruber roseus) in the Camargue, Southern France. N. Zeal. Entomol. 2002, 25, 87-89. [CrossRef]

69. Nelson, B.C.; Murray, M.D. The distribution of Mallophaga on the domestic Pigeon (Columba livia). Int. J. Parasitol. 1971, 1, 21-29. [CrossRef]

70. Clay, T. The Phtiraptera (Insecta) parasitic on flamingoes (Phoenicopteridae: Aves). J. Zool. Lond. 1974, 172, 483-490. [CrossRef]

71. Johnson, K.P.; Shreve, S.M.; Smith, V.S. Repeated adaptive divergence of microhabitat specialization in avian feather lice. BMC Biol. 2012, 10, 52. Available online: http:/ / www.biomedcentral.com/1741-7007/10/52 (accessed on 8 January 2022). [CrossRef] [PubMed]

72. Crompton, D.W.T. Birds as habitat for parasites. In Host-Parasite Evolution. General Principles and Avian Models; Clayton, D.H., Moore, J., Eds.; Oxford University Press: Oxford, UK, 1997; pp. 253-270. 
73. Bush, S.E.; Sohn, E.; Clayton, D.H. Ecomorphology of parasite attachment: Experiments with feather lice. J. Parasitol. 2006, 92, 25-31. [CrossRef] [PubMed]

74. Clayton, D.H.; Moyer, B.R.; Bush, S.E.; Jones, T.G.; Gardiner, D.W.; Rhodes, B.B.; Goller, F. Adaptive significance of avian beak morphology for ectoparasites control. Proc. R. Soc. Lond. B 2005, 272, 811-817. [CrossRef] [PubMed]

75. Fowler, J.A.; Williams, I.R. Population dynamics of Mallophaga and Acari on reed buntings occupying a communal winter roost. Ecol. Entomol. 1985, 10, 377-383. [CrossRef]

76. Clayton, D.H.; Lee, P.L.M.; Tompkins, D.M.; Brodie, E.D., III. Reciprocal natural selection on host-parasite phenotypes. Am. Nat. 1999, 154, 261-270. [CrossRef] [PubMed]

77. Rózsa, L. Patterns in the abundance of avian lice (Phthiraptera: Amblycera, Ischnocera). J. Avian Biol. 1997, 28, 249-254. [CrossRef]

78. Clayton, D.H.; Walther, B.A. Influence of host ecology and morphology on the diversity of Neotropical bird lice. Oikos 2001, 94, 455-467. [CrossRef]

79. Clayton, D.H.; Drown, D.M. Critical evaluation of five methods for quantifying chewing lice (Insecta: Phthiraptera). J. Parasitol. 2001, 87, 1291-1300. [CrossRef]

80. Miller, M.J.R.; Ewins, P.J.; Galloway, T.D. Records of ectoparasites collected on ospreys from Ontario. J. Wildl. Dis. 1997, 33, 373-376. [CrossRef]

81. Darolova, A.; Hoi, H.; Kristofik, J.; Hoi, C. Horizontal and vertical ectoparasites transmission of three species of mallophaga, and individual variation in European bee-eaters (Merops apiaster). J. Parasitol. 2001, 87, 256-262. [CrossRef] 